\title{
Pathobiological Influence of a Radiofrequency Ablation System
}

\author{
Keiji Inoue $^{a}$ Takashi Karashima $^{\text {a }}$ Tatsuo liyama $^{a}$ Shingo Ashida ${ }^{a}$ \\ Masayuki Kamada ${ }^{a}$ Taro Shuin $^{a}$ Parijatha Rao $^{b}$ Atsushi Kurabayashi ${ }^{c}$ \\ Mutsuo Furihata ${ }^{c}$ Akimitsu Hotta ${ }^{d}$

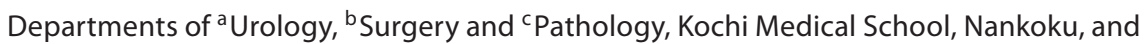 \\ d Department of Electronic and Phonic Systems Engineering, Kochi University of Technology, Kami, Japan
}

\section{Key Words}

Renal involvement • Minimally invasive therapy, kidney •

Nephron-sparing surgery $\cdot$ Radiofrequency ablation •

Electric and thermal conductivity

\begin{abstract}
Purpose: The objective of this study was to optimize the least invasive technique of radiofrequency ablation (RFA) for the degenerated renal parenchyma and to develop a novel RFA system. Materials and Methods: Tissue temperature and pathological degeneration were investigated at regular time intervals and distances from the RFA needle electrode in the renal parenchyma of the pig kidney. We also examined whether interruption of the renal artery or irrigation in the renal pelvis had an influence on the therapeutic effects. Results: Pathological investigations showed a core necrotic area surrounded by an ischemic layer around the needle electrode. Interestingly, interruption of the renal artery and irrigation in the renal pelvis markedly enhanced the degeneration of the parenchyma. Especially the electric conductivity of irrigation solutions in the renal pelvis influenced the therapeutic effect. In this novel system which retains the flow of electricity between the 2 electrodes and maintains the electric power at a constant wattage, a marked therapeutic effect was observed between the 2 electrodes rather than on their outsides, and this was not influenced by renal
\end{abstract}

artery interruption and/or renal parenchyma cooling. Conclusions: This novel RFA system may contribute to more effective and highly reproducible therapeutic results.

Copyright $\odot 2010$ S. Karger AG, Basel

\section{Introduction}

Renal cell carcinoma is the most common neoplasm of the kidney. There are up to 30,000 new cases/year reported in the USA [1]. Due to the increasing use of crosssectional imaging such as ultrasonography, computed tomography and magnetic resonance imaging, small incidental renal cell carcinomas in asymptomatic patients are detected with increasing frequency. Early diagnosis has increased the possibility of successfully removing these small tumors. Moreover, the development of image-guided interventional and video-assisted surgical techniques has largely facilitated minimally invasive surgical techniques, such as microwave tissue coagulation $[2,3]$ or radiofrequency ablation (RFA) $[4,5]$ for renal tumors.

Radiofrequency delivers a high-frequency (460-500 $\mathrm{kHz}$ ) alternating current into the tissue from a thin needle (usually 14-21 gauge) that is electrically exposed and a noninsulated portion of the electrode. As the current attempts to reach the grounding pad (usually placed on the patient's back or thigh), ion agitation is produced

\section{KARGER}

Fax +4161306 1234 E-Mail karger@karger.ch www.karger.com

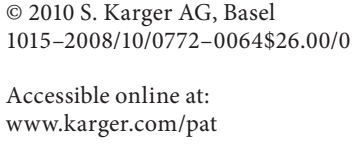


within the tissues surrounding the electrode. This agitation is converted by resistive friction into heat, inducing cellular death by coagulation and necrosis $[6,7]$.

Recently, these techniques have been applied percutaneously and endoscopically for enucleation and ablation of several types of tumor in the liver [8], lung [9] and kidney [10], and were used in combination with cooling of tissue around the treated area to avoid overtreatment beyond the margin of safety [11]; transcatheter arterial embolization was used to enhance the effect of these techniques $[12,13]$. However, results in recent animal and agar phantom modeling studies suggest that the determination of overall energy deposition and thermal ablation effectiveness of RFA depend on the tissue characteristics [14] and the surrounding environment such as blood flow [14-17] and electrothermal conductivity $[18,19]$.

Therefore, the purpose of our study was to determine histopathologically the effect of arterial embolization and cooling of tissue parenchyma as a modification of the surrounding environment on the distribution of tissue temperature and on the area of tissue degeneration by RFA in the kidney of a living pig. In an effort to improve the existing RFA protocol, we developed and evaluated a novel RFA system which was not influenced by the tissue condition, particularly the electric conductivity (EC) in and around the target area.

\section{Materials and Methods}

\section{Experimental Animals}

Twelve domestic female pigs weighing $39.4 \pm 3.6 \mathrm{~kg}$ (range $33.3-44.5 \mathrm{~kg}$ ) underwent RFA in a total of 36 lesions of the upper, lower and middle poles of the kidney (weight $151.1 \pm 12.4 \mathrm{~g}$, range $135.0-175.0 \mathrm{~g}$ ). The animal experiments were performed 3 times for every experimental design. The animals were subjected to general anesthesia induced by intramuscular injection of $15 \mathrm{mg} /$ $\mathrm{kg}$ of ketamine and intravenous injection of $5 \mathrm{mg} / \mathrm{kg}$ of sodium thiopental with tracheal intubation and respiratory assistance using a mixture of oxygen, halothane and nitrous oxide. The anesthesia and sacrifice of animals were performed in accordance with the guidelines of our institutional animal care and use committee.

\section{Therapeutic Equipment and Design}

Original RFA System

A monopolar needle electrode of the Cool-Tip Radiofrequency Ablation System (17 G, $20 \mathrm{~cm}$ in length with 20 -mm active probe; Tyco Healthcare Japan Inc., Tokyo, Japan) was inserted into a living pig kidney after opening the abdominal cavity under general anesthesia. The ablation was performed under impedance control. The power output was commenced at the electric power of $40 \mathrm{~W}$ and continuously increased by $20 \mathrm{~W}$ every $60 \mathrm{~s}$ until the generator stopped delivering radiofrequency energy due to a 20 - ohm or higher impedance increase of the ablated tissue from the baseline, the so-called break. The tissue parenchyma temperatures were measured at regular distances of $5.0 \mathrm{~mm}$ from the needle electrode and time intervals (10 s) using an 18 -mm needle temperature sensor, Mon-a-therm (Tyco Healthcare Japan Inc.). The histopathological changes of the tissue degeneration of the renal parenchyma were also evaluated by hematoxylin and eosin (HE) staining in the renal specimens obtained after treatment. In addition, we examined whether interruption of the renal artery or cooling of the renal parenchyma had an effect on the distribution of tissue temperature and the area of tissue degeneration. The interruption of the renal artery was performed by a hemostatic clamp. The cooling of the renal parenchyma was performed by infusion of $5^{\circ} \mathrm{C}$ irrigation solutions into the renal pelvis using a 6 -french ureteral catheter at an infusion speed of $1 \mathrm{ml} / \mathrm{s}$. We also examined whether cooling of the renal parenchyma by several irrigation solutions (normal saline solution, tap water and glucose) which have different EC would have an effect on the distribution of temperature and the area of tissue degeneration. The EC of these irrigation solutions was measured by an EC meter (MC126 Portable Conductivity Meter; Mettler Toledo KK, Tokyo, Japan).

Novel RFA System

We developed a novel RFA system which demonstrates the flow of electricity between the 2 electrodes $(17 \mathrm{G}, 20 \mathrm{~cm}$ in length with 20 -mm active probe). The ablation by a novel RFA system was performed with a stable power output not under impedance control. We evaluated the therapeutic effect of the novel RFA system in egg white and the pig kidney. In egg white, coagulation and solidification of the protein were observed at increasing time intervals. After $600 \mathrm{~s}$ of initiating ablation at $40 \mathrm{~W}$, the mass of coagulated protein was measured. In the kidneys of the pigs under general anesthesia, the tissue parenchyma temperatures were measured by 3 needle temperature sensors that were placed at the center and outside of the 2 RFA electrodes, and at various time intervals (10 s). The histopathological changes of the tissue degeneration of the renal parenchyma were also evaluated by the methods described above. We optimized the electric power by maintaining a constant wattage and also examined whether the interruption of the renal artery and cooling of the renal parenchyma by irrigation had any effect on the targeted area for therapy in the kidney.

Pathological Findings in the Original RFA System

Pathological investigations showed a necrotic layer in the core which was surrounded by an ischemic layer (fig. 1) - an inner proximal degenerated red blood cell (RBC) layer and an outer distal nondegenerated RBC layer around the RFA electrode. The necrotic and ischemic layers were visible as areas of irreversible tissue degeneration with no viable cells using HE staining and also immunohistochemistry for single-stranded DNA. A reversible layer of congested RBC surrounded the outer ischemic layer. These layers extend concentrically around the electrode just as a spheroid. The thickness of each layer was histopathologically measured as an evaluation of therapeutic effects and statistically analyzed using the Mann-Whitney test.

Pathological Findings in the Novel RFA System

In the kidney of the pig, 2 electrodes were placed at a distance of $20 \mathrm{~mm}$ (fig. 2). Three temperature sensors were placed at dis- 


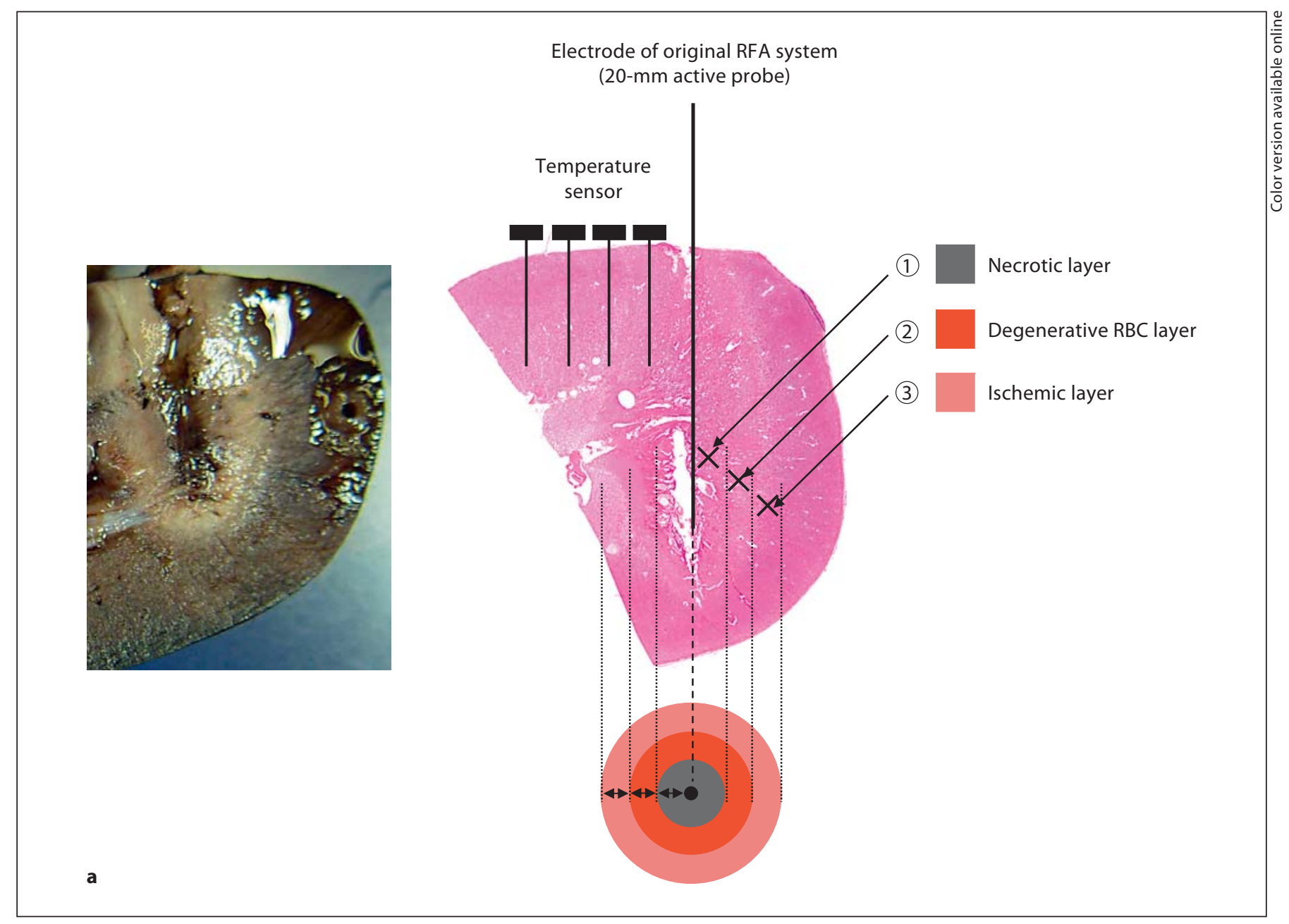

Fig. 1. Pathological investigation of the original RFA system. a The tissue parenchyma temperatures were measured at regular distances $(5.0 \mathrm{~mm})$ from the needle electrode of the original RFA system, and at regular time intervals (10 s) using needle temperature sensors in the pig's kidney under general anesthesia.

tances of $10 \mathrm{~mm}$ from the electrodes. The schematic diagram shows that the necrotic layer was seen around each electrode. The degenerative $\mathrm{RBC}$ layer was wider with the maximum area seen between the 2 electrodes, and the ischemic layer was seen around the degenerative RBC layer. The necrotic and ischemic layers were detected with irreversible tissue degeneration and no viable cells using HE staining and also immunohistochemistry for singlestranded DNA. Surrounding the outer ischemic layer, there was a reversible layer of congested $\mathrm{RBC}$. It looked as if the maximum effect of the electricity is between the 2 electrodes rather than on their outsides. The thickness of each layer was histopathologically measured as an evaluation of the therapeutic effects and statistically analyzed using the Mann-Whitney test.

Immunohistochemistry for Single-Stranded DNA

An immunohistochemical study was performed to detect cellular damage in situ on paraffin sections of pig kidneys using the
Ventana automated immunohistochemistry system (Discovery TM, Ventana Medical System Inc., Tucson, Ariz., USA). Cellular damage was identified with a polyclonal anti-single-stranded DNA antibody (1:500; Dako SA, Glostrup, Denmark) which recognizes DNA fragmentation caused by single-strand breaks in nuclei.

\section{Results}

\section{Tissue Temperature and Tissue Degeneration in the Original RFA System}

By RFA, the tissue temperature recording was $61.6^{\circ} \mathrm{C}$ at $5 \mathrm{~mm}$ after $110 \mathrm{~s}$ and $60.0^{\circ} \mathrm{C}$ at $10 \mathrm{~mm}$ after $250 \mathrm{~s}$, while the temperature at 20 or $30 \mathrm{~mm}$ was not above $50^{\circ} \mathrm{C}$ 


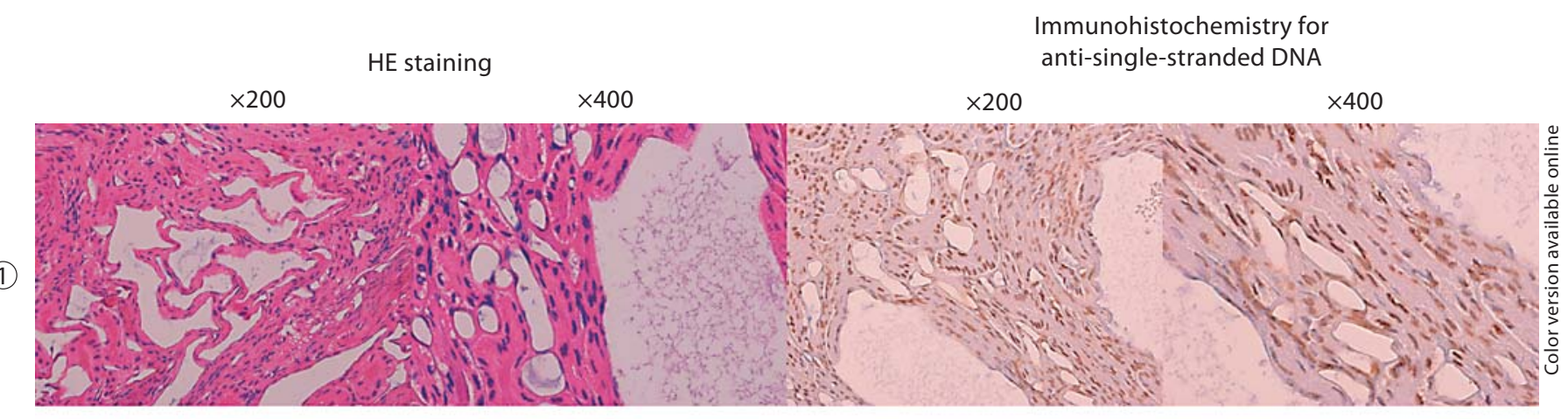

(2)

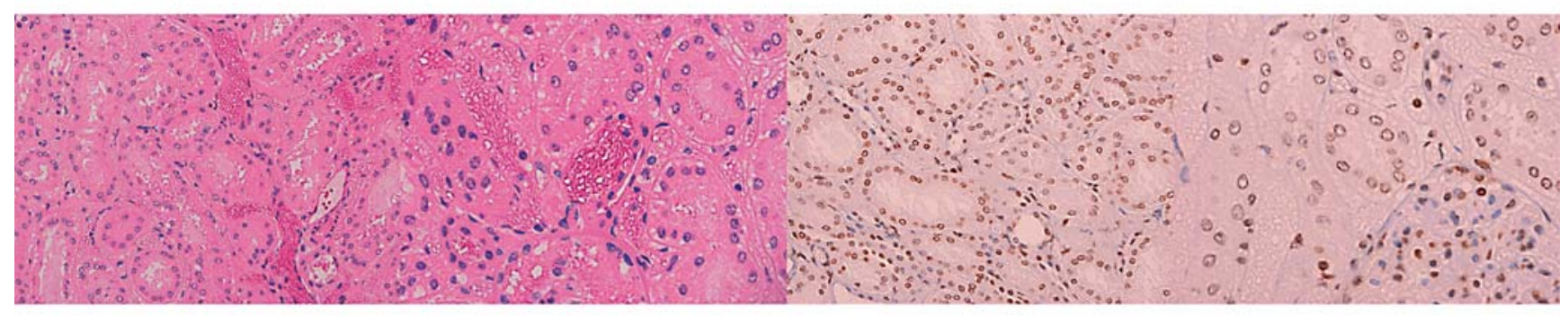

(3)

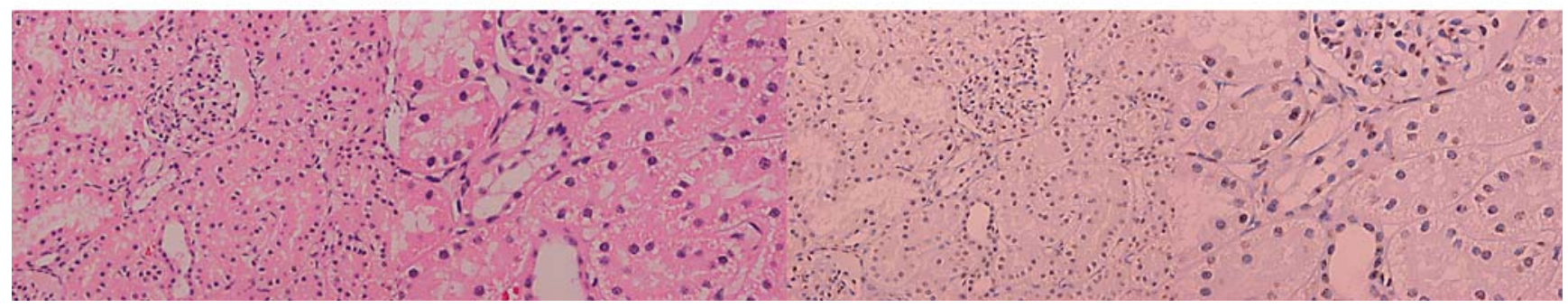

Fig. 1. Pathological investigation of the original RFA system. b Pathological investigations by using HE staining and also immunohistochemistry for single-stranded DNA showed a necrotic layer (1) in the core surrounded by a degenerated RBC layer (2) and an ischemic layer (3) around the electrode of the original RFA system. Surrounding the outer ischemic layer, there is a reversible layer of congested RBC.

(fig. 3, table 1). The area showing irreversible tissue degeneration, detected by HE staining and also immunohistochemistry for single-stranded DNA, was in total $21.0 \mathrm{~mm}$, of which $4.0 \mathrm{~mm}$ was the necrotic layer and 17.0 $\mathrm{mm}$ the ischemic layer, inclusive of a 9.5-mm layer of degenerated RBC detected from the RFA electrode.

Interestingly, it was observed that both interruption of the renal artery and cooling of the renal parenchyma markedly enhanced both the tissue temperature and the area of tissue degeneration. When RFA was performed along with interruption of the renal artery and cooling of the renal parenchyma, the tissue temperature recording was above $60^{\circ} \mathrm{C}$ at $5 \mathrm{~mm}$ after $70 \mathrm{~s}$, at $10 \mathrm{~mm}$ after $100 \mathrm{~s}$, at $15 \mathrm{~mm}$ after $220 \mathrm{~s}$ and at $20 \mathrm{~mm}$ after $310 \mathrm{~s}$, and the irreversible tissue degeneration area was increased to a total of $41.0 \mathrm{~mm}$, of which $11.0 \mathrm{~mm}$ was the necrotic layer and $30.0 \mathrm{~mm}$ the ischemic layer, inclusive of a $17.0-\mathrm{mm}$ layer of degenerated RBC from the RFA electrode. There were statistically significant differences in the range of each layer compared to the control group (total area, necrotic layer: $\mathrm{p}<0.01$; ischemic layer, degenerative $\mathrm{RBC}$ layer: $\mathrm{p}<0.05)$.

\section{Comparison of Several Irrigation Solutions in the Original RFA System}

Furthermore, we examined if cooling of the renal parenchyma by several irrigation solutions $\left(5^{\circ} \mathrm{C}\right)$, such as normal saline solution, tap water and glucose solution, applied to the renal pelvis using a ureteral catheter, would influence the distribution of temperature and the area of tissue degeneration (fig. 4, table 2). The EC of normal saline solution, tap water and glucose solution was measured by an EC meter (MC126 Portable Conductivity Meter; Mettler Toledo KK), showing EC of 15,800, 133 and 


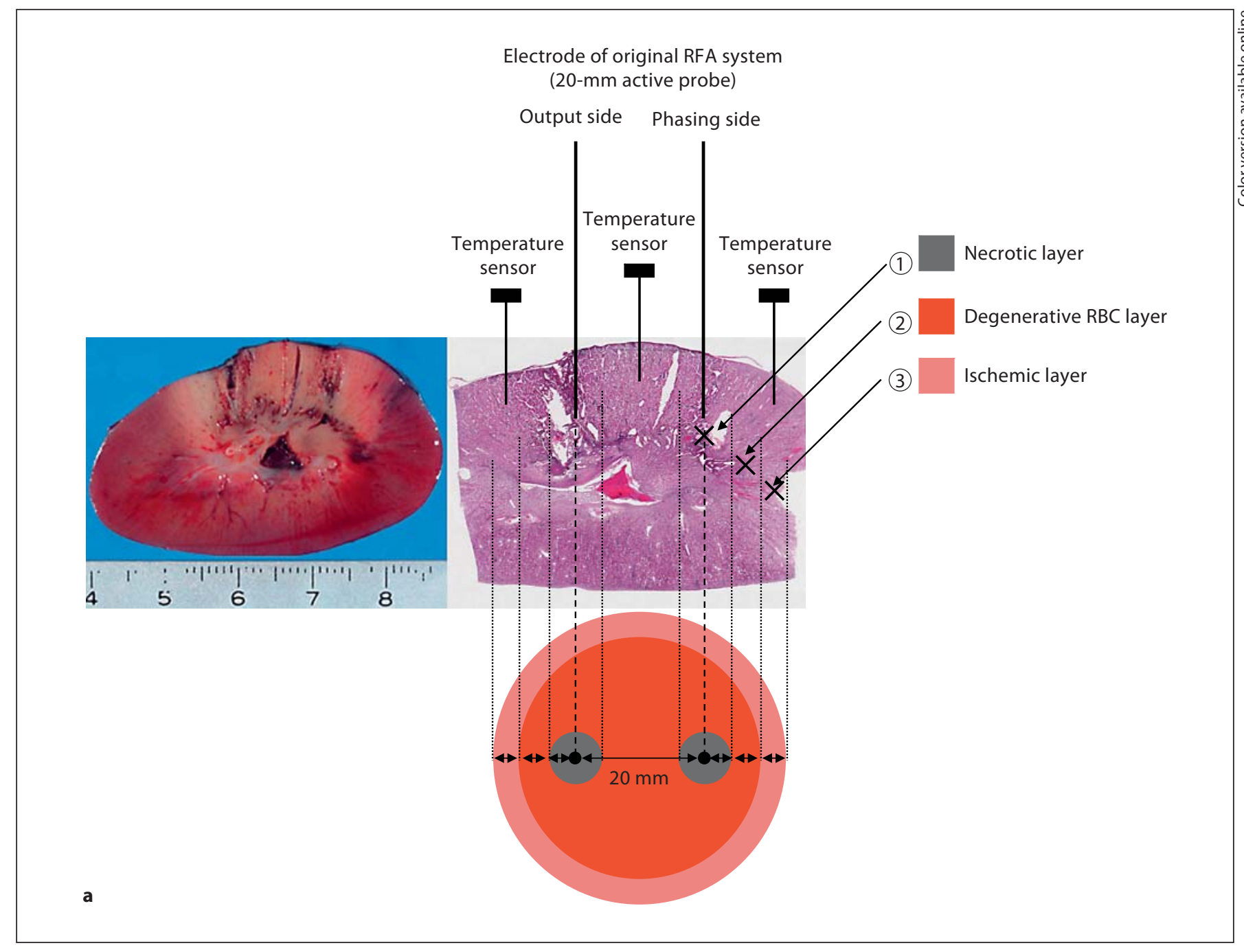

Fig. 2. Pathological investigation of the novel RFA system. a In the kidney of the pig, the tissue parenchyma temperatures were measured by 3 temperature sensors placed in the center and outside of the 2 RFA electrodes, at various time intervals $(10 \mathrm{~s})$.

$8.6 \mu \mathrm{S} / \mathrm{cm}$, respectively. In microwave tissue coagulation and ultrasound, these solutions did not have any effect on the distribution of temperature and on the area of tissue degeneration.

However, in RFA cooling of the renal parenchyma by normal saline solution, the tissue temperature recording read $63.9^{\circ} \mathrm{C}$ at $5 \mathrm{~mm}$ after $30 \mathrm{~s}, 60.0^{\circ} \mathrm{C}$ at $10 \mathrm{~mm}$ after $80 \mathrm{~s}, 60.6^{\circ} \mathrm{C}$ at $15 \mathrm{~mm}$ after $200 \mathrm{~s}$ and $60.0^{\circ} \mathrm{C}$ at $20 \mathrm{~mm}$ after $300 \mathrm{~s}$, whereas with glucose solution, the tissue temperature recording was $60.3^{\circ} \mathrm{C}$ at $5 \mathrm{~mm}$ after $360 \mathrm{~s}$, but there was no pause of generator output caused by an excessive increase in tissue impedance. These results indicate that in RFA along with cooling of the renal paren- chyma, the degree of tissue temperature elevation was enhanced by normal saline solution and reduced by glucose solution when compared to that of tap water and untreated groups.

The total area of irreversible tissue degeneration was $37.0 \mathrm{~mm}$, of which $9.5 \mathrm{~mm}$ was the necrotic layer and 27.5 $\mathrm{mm}$ the ischemic layer, inclusive of a 13.0-mm layer of degenerated RBC detected from the RFA electrode. There were statistically significant differences in the range of each layer compared to the control group (necrotic layer, ischemic layer: $\mathrm{p}<0.01$; total area: $\mathrm{p}<0.05)$ and the group treated with glucose solution (necrotic layer, ischemic layer: $\mathrm{p}<0.01$; total area: $\mathrm{p}<0.05$ ). In contrast, with glu- 


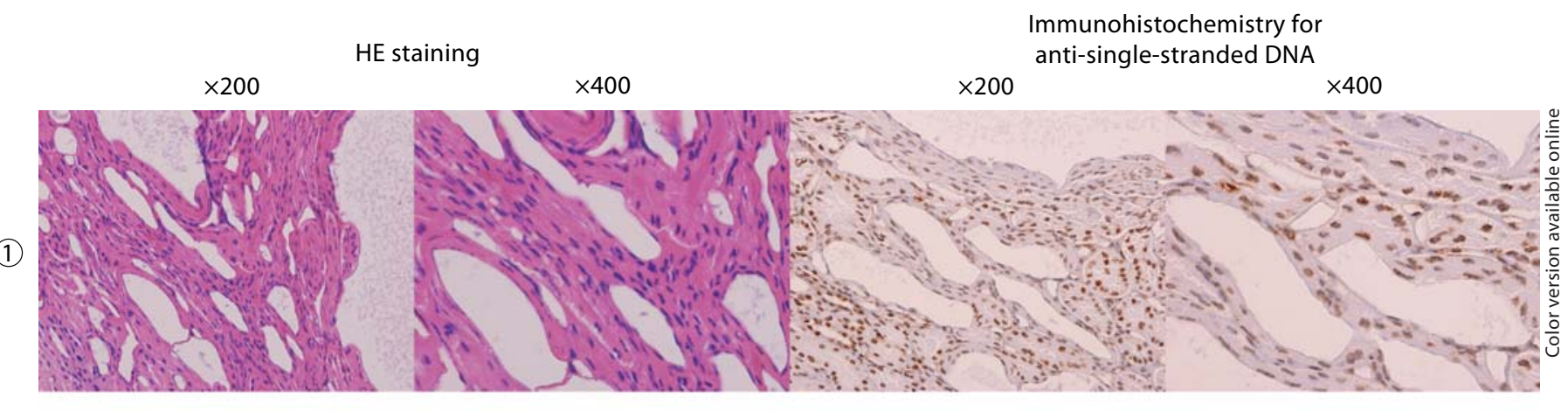

(2)

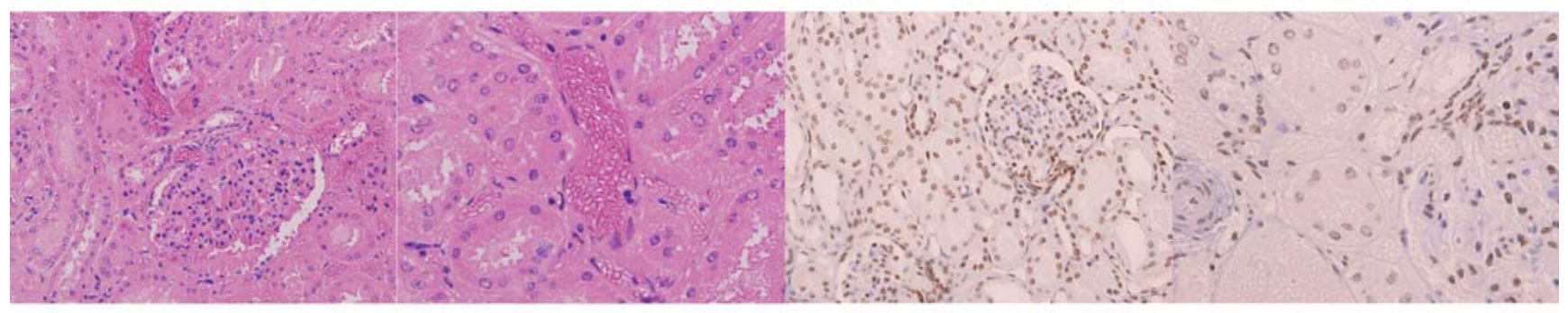

(3)

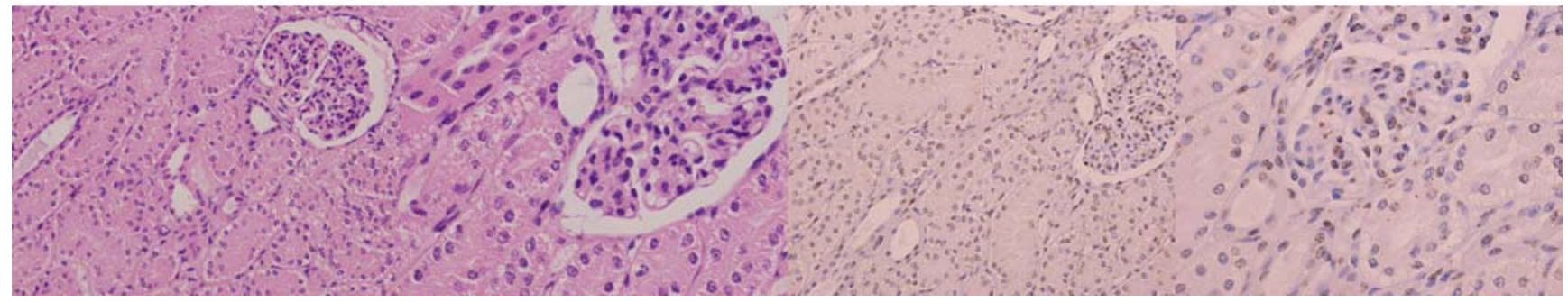

Fig. 2. Pathological investigation of the novel RFA system. b From pathological investigations using HE staining and also immunohistochemistry for single-stranded DNA, we see that the necrotic layer (1) was observed around the electrodes, individually. The degenerative RBC layer (2) was wider with the maximum area seen between the 2 electrodes, and the ischemic layer (3) was seen around the degenerative RBC layer. Surrounding the outer ischemic layer, there is a reversible layer of congested RBC. This also strongly suggests that the maximum effect of the electricity is between the 2 electrodes rather than on the outsides. Temperature sensor: 18$\mathrm{mm}$ needle type; temperature monitor: Mon-a-therm (Tyco Healthcare Japan Inc.).

cose solution, the total area of irreversible tissue degeneration was in total $14.0 \mathrm{~mm}$, of which $2.0 \mathrm{~mm}$ was the necrotic layer and $12.0 \mathrm{~mm}$ the ischemic layer, inclusive of an 8.5-mm layer of degenerated RBC detected from the RFA electrode. These results indicate that in RFA with cooling of the renal parenchyma, the area of tissue degeneration increased with normal saline solution and was decreased with glucose solution when compared to that treated with tap water and to the untreated groups.

\section{The Coagulation and Solidification of the Egg White}

Protein in the Novel RFA System

We used egg white to demonstrate the flow of electricity between the 2 electrodes (fig. 5). From the photo- graphs we see that the movement of the egg white is towards the electrodes. The coagulation and solidification of the protein are directly proportional to time. When the coagulated mass was cut transversely, we observed that the protein coagulation was most marked between the electrodes $(20 \mathrm{~mm})$ rather than at the extremities (6.4 and $7.5 \mathrm{~mm}$ ). The coagulation was also more marked on the upper side of the electrical field $(22.0 \mathrm{~mm})$ rather than the lower side $(4.2 \mathrm{~mm})$. From this experiment, we came to understand that the flow of current is most intense between the electrodes. This ensures maximum damage to the concerned tissue with minimal effects to the surrounding normal tissue. 
Fig. 3. The distribution of tissue temperature of renal parenchyma treated by the original RFA system with/without interruption (I) of the renal artery and/or cooling $(\mathrm{C})$ of the renal parenchyma by irrigation with tap water in the renal pelvis using a ureteral catheter. In the original RFA system, interruption of the renal artery and cooling of the renal parenchyma markedly increased the tissue temperature.

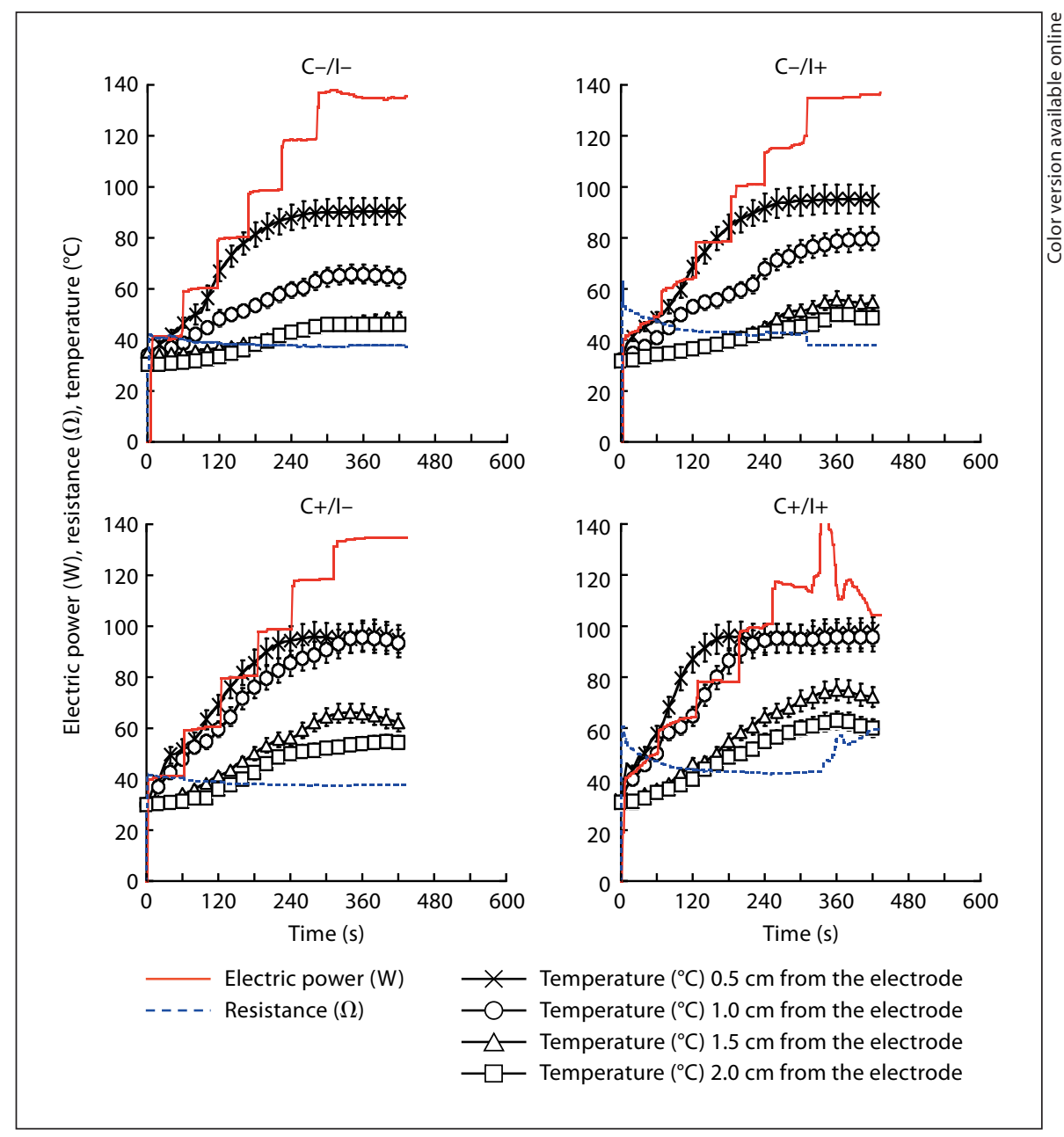

Table 1. The effect on the area of tissue degeneration $(\mathrm{mm})$ by the interruption of the renal artery and/or cooling of the renal parenchyma

\begin{tabular}{lcccl}
\hline & \multicolumn{2}{l}{ Original RFA system $(2$-cm electrode $)$} \\
\cline { 2 - 5 } & I-/C- & I+/C- & I-/C+ & I+/C+ \\
\hline Necrotic layer & $4.0 \pm 0.5$ & $5.0 \pm 0.5$ & $7.5 \pm 1.0^{*}$ & $11.0 \pm 1.5^{* *}$ \\
Degenerative RBC layer & $9.5 \pm 1.0$ & $10.0 \pm 1.0$ & $13.0 \pm 1.5$ & $17.0 \pm 1.5^{*}$ \\
Ischemic layer & $7.5 \pm 1.5$ & $9.0 \pm 2.0$ & $10.5 \pm 2.5^{*}$ & $13.0 \pm 3.0^{*}$ \\
\hline Total area of effect (diameter) & $21.0 \pm 3.0$ & $24.0 \pm 3.5$ & $31.0 \pm 5.0^{*}$ & $41.0 \pm 6.0^{* *}$
\end{tabular}

$\mathrm{I}=$ Interruption of the renal artery; $\mathrm{C}=$ cooling of the renal parenchyma by irrigation with tap water in the renal pelvis using a ureteral catheter. ${ }^{*} \mathrm{p}<0.05,{ }^{* *} \mathrm{p}<0.01$ against control group (I-/C-; Mann-Whitney test). The table represents the total area of irreversible tissue degeneration including necrotic, degenerative
$\mathrm{RBC}$ and ischemic layers detected by HE staining and also immunohistochemistry for single-stranded DNA in the kidney. In the original RFA system, both interruption of the renal artery and cooling of the renal parenchyma markedly increased the area showing irreversible tissue degeneration. 
Fig. 4. The distribution of tissue temperature of renal parenchyma treated by the original RFA system with cooling of the renal parenchyma by several irrigation solutions such as normal saline solution, tap water and glucose solution in the renal pelvis using a ureteral catheter. We examined whether cooling of the renal parenchyma by several irrigation solutions $\left(5^{\circ} \mathrm{C}\right)$ would have an effect on the distribution of temperature. The EC of normal saline solution, tap water and glucose solution was measured by an EC meter (MC126 Portable Conductivity Meter; Mettler Toledo $\mathrm{KK}$ ), and was $15,800,133$ and $8.6 \mu \mathrm{S} / \mathrm{cm}$, respectively. In the original RFA system, cooling of the renal parenchyma by normal saline solution enhanced the degree of tissue temperature elevation compared to that of tap water and untreated groups.

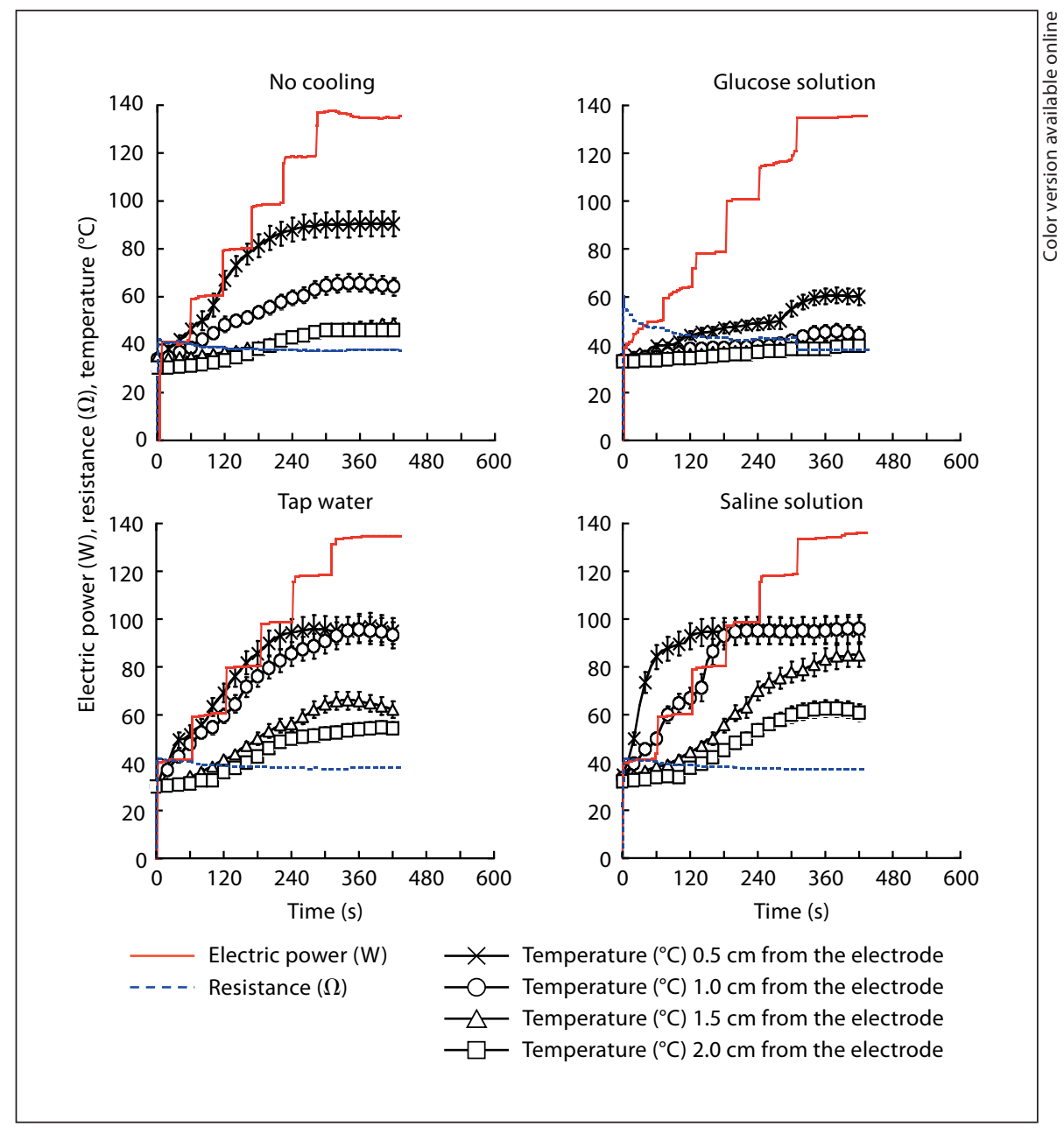

Table 2. The effect on the area of tissue degeneration $(\mathrm{mm})$ by cooling of the renal parenchyma with several irrigation solutions

\begin{tabular}{lcccc}
\hline & Original RFA system $(2$-cm electrode) & & \\
\cline { 2 - 5 } & no cooling & $\begin{array}{c}\text { glucose solution } \\
(\mathrm{EC}: 8.6 \mu \mathrm{S} / \mathrm{cm})\end{array}$ & $\begin{array}{c}\text { tap water } \\
(\mathrm{EC}: 133 \mu \mathrm{S} / \mathrm{cm})\end{array}$ & $\begin{array}{l}\text { saline solution } \\
(\mathrm{EC}: 15,800 \mu \mathrm{S} / \mathrm{cm})\end{array}$ \\
\hline Necrotic layer & & $2.0 \pm 0.0$ & $7.5 \pm 1.0^{\mathrm{a}, \mathrm{d}}$ & $9.5 \pm 1.0^{\mathrm{b}, \mathrm{d}}$ \\
Degenerative RBC layer & $4.0 \pm 0.5$ & $8.5 \pm 1.0$ & $13.0 \pm 1.5$ & $13.0 \pm 2.0$ \\
Ischemic layer & $9.5 \pm 1.0$ & $3.5 \pm 0.0^{\mathrm{a}}$ & $10.5 \pm 2.5^{\mathrm{a}, \mathrm{c}, \mathrm{d}}$ & $14.5 \pm 3.0^{\mathrm{b}, \mathrm{d}}$ \\
\hline Total area of effect (diameter) & $21.0 \pm 3.0$ & $14.0 \pm 1.0^{\mathrm{a}}$ & $31.0 \pm 5.0^{\mathrm{a}, \mathrm{c}}$ & $37.0 \pm 6.0^{\mathrm{a}, \mathrm{c}}$
\end{tabular}

The EC of normal saline solution, tap water and glucose solution was measured by an EC meter (MC126 Portable Conductivity Meter; Mettler Toledo KK). ${ }^{\mathrm{a}} \mathrm{p}<0.05,{ }^{\mathrm{b}} \mathrm{p}<0.01$ against control group (no cooling; Mann-Whitney test); ${ }^{\mathrm{c}} \mathrm{p}<0.05,{ }^{\mathrm{d}} \mathrm{p}<0.01$ against the group treated with glucose solution (Mann-Whitney test). This table represents the observations when glucose, tap water and saline were used as irrigating fluids. The total area of effect was minimal with glucose and maximal with saline. There was a significant difference in the area between tap water and saline. We examined whether cooling of the renal parenchyma by these irrigation solutions $\left(5^{\circ} \mathrm{C}\right)$ would have an effect on the distribution of temperature. In the original RFA system, cooling of the renal parenchyma by normal saline solution enhanced the degree of tissue temperature elevation compared to that of tap water and untreated groups. 
Fig. 5. Experimental model using egg white. We used egg white to demonstrate the flow of electricity between the 2 electrodes of the novel RFA system. From the photographs, we see that the movement of the egg white is towards the electrodes. The coagulation and solidification of the protein are directly proportional to time. When the coagulated mass was cut transversely, we observed that the protein coagulation was most marked between the electrodes $(20 \mathrm{~mm})$ compared to the outsides $(6.4$ and $7.5 \mathrm{~mm}$ ). The coagulation was also more marked on the upper side of the electrical field $(22.0 \mathrm{~mm})$ than the lower side $(4.2 \mathrm{~mm})$.

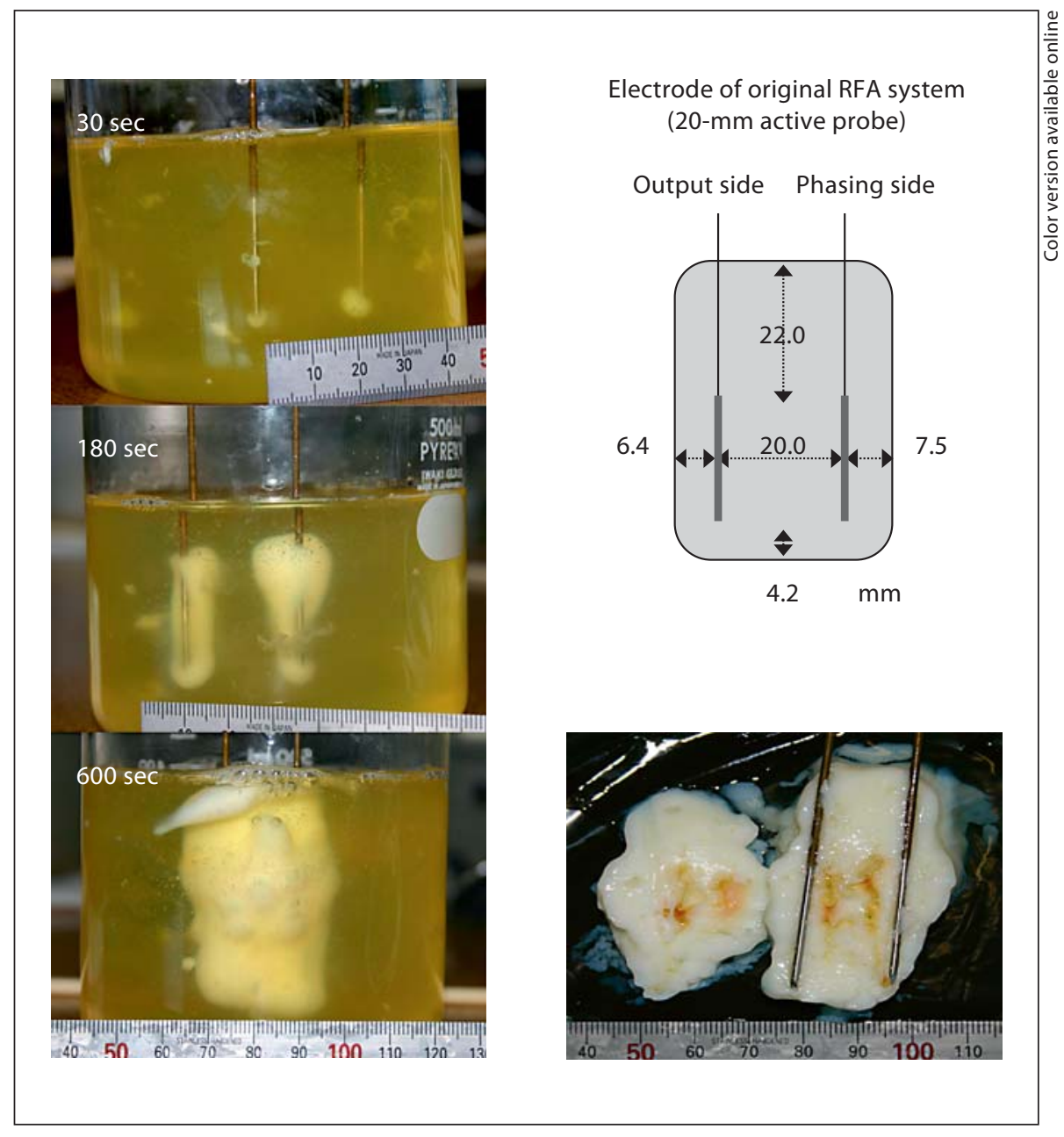

\section{Tissue Temperature and Tissue Degeneration in the}

Novel RFA System

In this novel RFA system, we investigated differences in electrode distances with $40 \mathrm{~W}$ of stably maintained electric power (fig. 6, 7, tables 3, 4). The effect at the distance of $3 \mathrm{~cm}$ was minimal, and at $1 \mathrm{~cm}$ it was rapid. The distance of $2 \mathrm{~cm}$ showed a significant effect; the difference in effects between 2 and $1 \mathrm{~cm}$ was not statistically significant. As the damage with $2 \mathrm{~cm}$ was high and stable, it was considered for the experimental system (fig. 6, table 3).

In this novel RFA system, we then investigated differences in electric power with $2 \mathrm{~cm}$ as the fully fixed electrode distance. The effect at $20 \mathrm{~W}$ was minimal, and the effect at $80 \mathrm{~W}$ was rapid. Forty watts showed a significant effect; the difference in effects between 80 and $40 \mathrm{~W}$ was not statistically significant. As the damage with $40 \mathrm{~W}$ was high and yet stable, it was considered for the experimental system (fig. 7, table 4).

\section{Comparison of Several Irrigation Solutions in the Novel RFA System}

We also examined whether cooling of the renal parenchyma by several irrigation solutions $\left(5^{\circ} \mathrm{C}\right)$ such as normal saline solution, tap water and glucose solution in the renal pelvis using a ureteral catheter would have an effect on the distribution of temperature and the area of tissue degeneration in the novel RFA system (fig. 8, table 5). Based on the above results, we determined that the distance between electrodes was fixed at $2 \mathrm{~cm}$, and the electric power was maintained at $40 \mathrm{~W}$.

We observed that interruption of the renal artery and cooling of the renal parenchyma by irrigation did not have any effect on the distribution of temperature, which was contrary to the original hypothesis. 


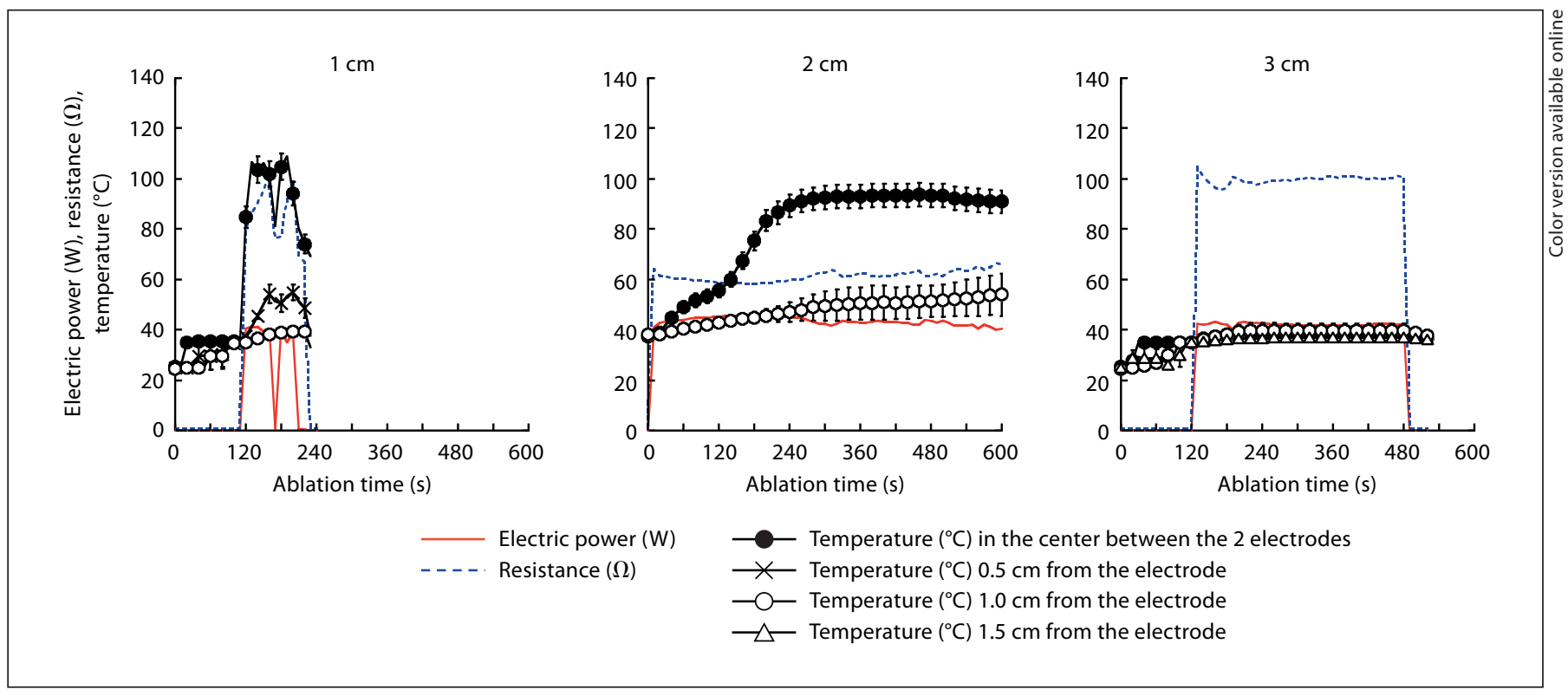

Fig. 6. The distribution of tissue temperature of renal parenchyma treated at $40 \mathrm{~W}$ of electric power stratified by the distance between the electrodes of the novel RFA system. The effect at the distance of $3 \mathrm{~cm}$ was minimal, and at $1 \mathrm{~cm}$ it was rapid. A distance of $2 \mathrm{~cm}$ showed a significant effect, and the difference in effects between 2 and $1 \mathrm{~cm}$ was not statistically significant. As the damage with $2 \mathrm{~cm}$ was high and stable, it was considered for the experimental system.

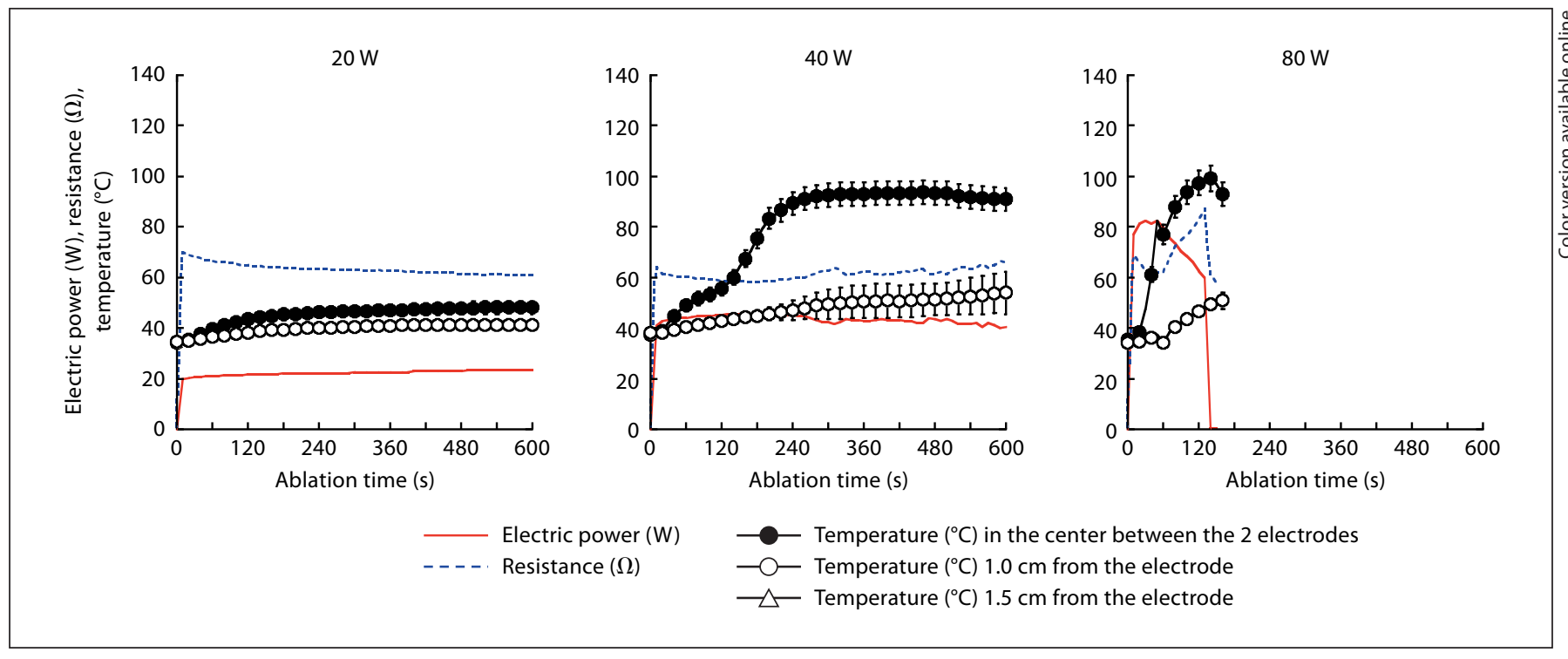

Fig. 7. The distribution of tissue temperature of renal parenchyma treated with $2 \mathrm{~cm}$ of electrode distance stratified by the electric power of the novel RFA system. The effect at $20 \mathrm{~W}$ was minimal, and at $80 \mathrm{~W}$ it was rapid. Forty watts showed a significant effect, and the difference in effects between 80 and $40 \mathrm{~W}$ was not statistically significant. As the damage with $40 \mathrm{~W}$ was high and stable, it was considered for the experimental system. 
Table 3. The effect on the area of tissue degeneration $(\mathrm{mm})$ by double-electrode RFA at 1,2 and $3 \mathrm{~cm}$ between the electrodes

\begin{tabular}{|c|c|c|c|c|c|c|}
\hline & \multicolumn{6}{|c|}{ Novel RFA (2-cm electrode) } \\
\hline & \multicolumn{2}{|l|}{$1 \mathrm{~cm}$} & \multicolumn{2}{|l|}{$2 \mathrm{~cm}$} & \multicolumn{2}{|l|}{$3 \mathrm{~cm}$} \\
\hline & output & phasing & output & phasing & output & phasing \\
\hline Necrotic layer & $0.0 \pm 0.0$ & $0.0 \pm 0.0$ & $1.5 \pm 0.5$ & $0.5 \pm 0.0$ & $0.0 \pm 0.0$ & $0.0 \pm 0.0$ \\
\hline Degenerative RBC layer & $1.5 \pm 0.5$ & $0.0 \pm 0.0$ & $2.5 \pm 0.5$ & $1.0 \pm 0.0$ & $0.0 \pm 0.0$ & $0.0 \pm 0.0$ \\
\hline Ischemic layer & $2.0 \pm 0.5$ & $1.0 \pm 0.0$ & $3.5 \pm 1.5$ & $3.5 \pm 1.0$ & $0.0 \pm 0.0$ & $0.0 \pm 0.0$ \\
\hline Total area of effect (diameter) & \multicolumn{2}{|c|}{$14.5 \pm 1.0$} & \multicolumn{2}{|c|}{$32.5 \pm 3.5$} & \multicolumn{2}{|c|}{$0.0 \pm 0.0$} \\
\hline
\end{tabular}

No statistical significance between electric powers of 40 and $80 \mathrm{~W}$ (Mann-Whitney test). The table shows the effect of electrode distances on the area of effect. There was no tissue damage at $3 \mathrm{~cm}$. The damage at $1 \mathrm{~cm}$ was rapid, while there was no significant difference in the area of damage compared to that at $2 \mathrm{~cm}$. As the damage with $2 \mathrm{~cm}$ was high and stable, it was considered for the experimental system.

Table 4. The effect on the area of tissue degeneration $(\mathrm{mm})$ by double-electrode RFA at 20, 40 and $80 \mathrm{~W}$ of electric power

\begin{tabular}{|c|c|c|c|c|c|c|}
\hline & \multicolumn{6}{|c|}{ Novel RFA (2-cm electrode) } \\
\hline & \multicolumn{2}{|l|}{$20 \mathrm{~W}$} & \multicolumn{2}{|l|}{$40 \mathrm{~W}$} & \multicolumn{2}{|l|}{$80 \mathrm{~W}$} \\
\hline & output & phasing & output & phasing & output & phasing \\
\hline Necrotic layer & $0.0 \pm 0.0$ & $0.0 \pm 0.0$ & $1.5 \pm 0.5$ & $0.5 \pm 0.0$ & $1.0 \pm 0.0$ & $1.0 \pm 0.0$ \\
\hline Degenerative RBC layer & $0.0 \pm 0.0$ & $0.0 \pm 0.0$ & $2.5 \pm 0.5$ & $1.0 \pm 0.0$ & $0.5 \pm 0.0$ & $0.5 \pm 0.0$ \\
\hline Ischemic layer & $0.0 \pm 0.0$ & $0.0 \pm 0.0$ & $3.5 \pm 1.5$ & $3.5 \pm 1.0$ & $3.5 \pm 1.0$ & $4.5 \pm 1.5$ \\
\hline Total area of effect (diameter) & \multicolumn{2}{|c|}{$0.0 \pm 0.0$} & \multicolumn{2}{|c|}{$32.5 \pm 3.5$} & \multicolumn{2}{|c|}{$31.0 \pm 2.5$} \\
\hline
\end{tabular}

No statistical significance between electric powers of 40 and $80 \mathrm{~W}$ (Mann-Whitney test). The table shows the effect of constant current on the area of effect. There was no tissue damage at $20 \mathrm{~W}$. The damage at $80 \mathrm{~W}$ was rapid, while there was no significant difference in the area of damage compared to that at $40 \mathrm{~W}$. As the damage with $40 \mathrm{~W}$ was high and stable, it was considered for the experimental system.

\section{Discussion}

RFA uses the thermal effect of high-frequency current flow; when $460-500 \mathrm{kHz}$ flow through tumoral tissue, the conduction of the radiofrequency current by the cellular fluid causes molecular friction and production of heat. This heat energy leads to tissue necrosis due to denaturation, desiccation and coagulation [20].

Recently, RFA has been applied percutaneously and endoscopically for enucleation and ablation of renal tumor as the least invasive technique. The earliest report on RFA used for treating renal cancer demonstrated the ablation of interstitial tissue to treat renal tumors [21]. However, the clinical effects of RFA thus far were poorly representative. Therefore, in this study, we optimized RFA by evaluating the distribution of tissue temperature and the area of tissue degeneration of the kidney. The results strongly suggested that a given environmental characteristic (i.e. blood flow or tissue EC) significantly influenced the ablation outcome and energy deposition of RFA. There were however a few points of major concern with this protocol. The distribution of tissue temperature and the area of tissue degeneration by this technique depend on the surroundings of the treated area. The phasing plate was located at a distance outside of the tumor area. As a result, the total tissue field exposed to the radiofrequency would be wider, causing damage to the surrounding tissue as well. Interruption of the renal 


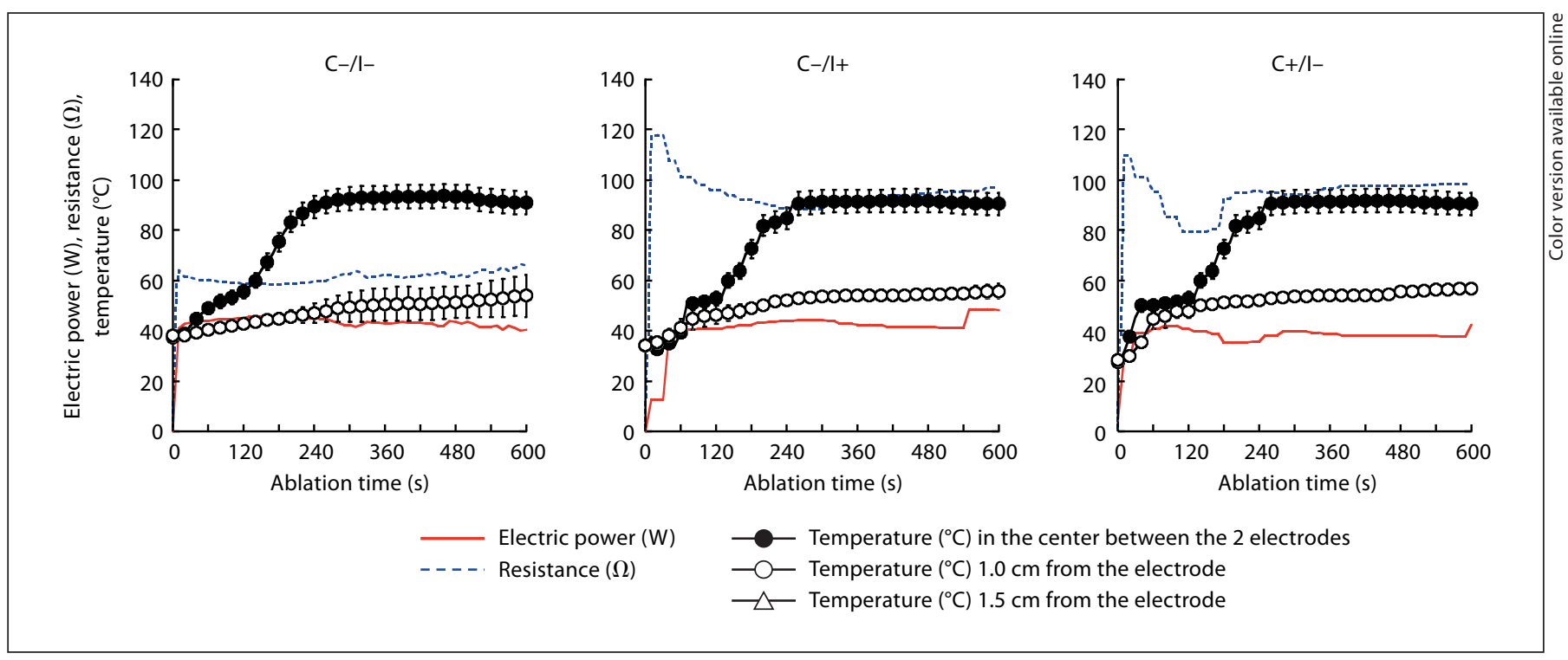

Fig. 8. The distribution of tissue temperature of renal parenchyma treated by the novel RFA system at $40 \mathrm{~W}$ of electric power with/without interruption (I) of the renal artery and/or cooling (C) of the renal parenchyma by irrigation with tap water in the renal pelvis using a ureteral catheter. In the novel RFA system, interruption of the renal artery and cooling of the renal parenchyma by irrigation did not have any effect on the distribution of temperature.

Table 5. The effect on the area of tissue degeneration $(\mathrm{mm})$ by cooling of the renal parenchyma with saline solution and interruption of the renal artery by double-electrode RFA at $40 \mathrm{~W}$ of electric power

\begin{tabular}{|c|c|c|c|c|c|c|}
\hline & \multicolumn{6}{|c|}{ Novel RFA (2-cm electrode) } \\
\hline & \multicolumn{2}{|l|}{ control } & \multicolumn{2}{|c|}{$\begin{array}{l}\text { saline solution } \\
(\mathrm{EC}: 15,800 \mu \mathrm{S} / \mathrm{cm})\end{array}$} & \multicolumn{2}{|c|}{ interruption of renal artery } \\
\hline & output & phasing & output & phasing & output & phasing \\
\hline Necrotic layer & $1.5 \pm 0.5$ & $0.5 \pm 0.0$ & $1.5 \pm 0.5$ & $1.0 \pm 0.5$ & $0.5 \pm 0.0$ & $1.5 \pm 0.5$ \\
\hline Degenerative RBC layer & $2.5 \pm 0.5$ & $1.0 \pm 0.0$ & $2.0 \pm 0.5$ & $2.0 \pm 0.5$ & $5.0 \pm 2.5$ & $1.5 \pm 0.5$ \\
\hline Ischemic layer & $3.5 \pm 1.5$ & $3.5 \pm 1.0$ & $2.5 \pm 1.0$ & $2.5 \pm 1.0$ & $1.0 \pm 0.0$ & $4.0 \pm 1.0$ \\
\hline Total area of effect (diameter) & \multicolumn{2}{|c|}{$32.5 \pm 3.5$} & \multicolumn{2}{|c|}{$32.5 \pm 4.0$} & \multicolumn{2}{|c|}{$33.5 \pm 4.5$} \\
\hline
\end{tabular}

No statistical significance between any group (Mann-Whitney test). The table shows the individual effect of saline as the irrigating fluid and interruption of the renal artery on the area of tissue damage. Cooling of the renal parenchyma and interruption of the renal artery are mutually exclusive in the tissue damage area. In the novel RFA system, interruption of the renal artery and cooling of the renal parenchyma by irrigation did not have any effect on the distribution of temperature.

artery and cooling of the renal parenchyma by irrigation doubled the diameter of the area of irreversible tissue degeneration. Moreover, the original RFA system concentrated on maintaining a constant voltage. However, this would result in an unstable current flow depending on the resistance since impedance and resistance are in- versely proportional. This unstable current flow would result in poorly representative clinical results. To avoid the influence of the EC in the tissue around the treated area, the electrode needle should be placed adjacent to the treated area instead of an electrode plate set at a distance from the electrode. Therefore, we proposed the al- 
ternative steps mentioned below in order to maintain the stability of the distribution of tissue temperature and to exert control on the area of tissue degeneration treated by RFA.

The inconsistency of the original system with regard to the current flow led to further improvements in the novel RFA system. Its electrode differs from the large needles like the LeVeen needle (Boston Scientific Co.) and handpiece (RITA Medical Systems). The novel RFA approach has provided a better effect than the original RFA as the phasing electrode is closer to the output electrode without a phasing/grounding pad. This not only streamlines the flow of electricity, but also intensifies the effect between the two electrodes and reduces the damage to the surrounding normal tissue. The increase in tissue temperature and the expansion of tissue degeneration by this novel RFA system were markedly accelerated between the 2 electrodes. It also ensures minimal wastage of current between the 2 electrodes and damage to the immediately surrounding normal tissue. This principle was re-enforced by the coagulation experiment with egg white protein which demonstrated that the coagulation was maximal between the 2 electrodes when compared to their outer margins. For a reliable effect on the tissue requiring ablation, a consistent flow of current is essential. Another important point of interest of this modification is that the current stream is kept stable, irrespective of the voltage and resistance. This ensures optimum and stable current flow executing maximum damage to the concerned tissue areas and minimal effect on the surrounding normal tissue. This demonstration shows that the tissue temperature and the tissue degeneration by the novel RFA system were independent of the environmental conditions, especially the EC in and around the target area.

The inferences from the original RFA system are that the radiofrequency tends to concentrate in the region with high EC, that the tissue around the treated area was directly influenced by the electric current, and that the variation of electric current corresponded to the variation of electric power supplied from the power source and resulted in low reproducibility of the original RFA treatment. The conclusion from the novel RFA system is that the changing blood flow and tissue EC have parallel consequences to the changes in the characteristics of normal tissue surrounding the tumor. This has direct implications with respect to the clinical application of radiofrequency energy for tumor destruction. The equipments for RFA must be used after understanding the tissue condition, especially the EC around the therapeutic target area. This novel RFA system may contribute to more effective and representative therapeutic results.

\section{References}

1 Jemal A, Siegel R, Ward E, Murray T, Xu J, Thun MJ: Cancer statistics, 2007. Cancer J Clinicians 2007;57:43-66.

-2 Iinuma M, Tsuchiya N, Satoh S, Ohyama C, Kato T, Sato K, Habuchi T: Retroperitoneoscopic partial nephrectomy by using microwave tissue coagulation. Hinyokika Kiyo 2004;50:299-303.

-3 Murota T, Kawakita M, Oguchi N, Shimada O, Danno S, Fujita I, Matsuda T: Retroperitoneoscopic partial nephrectomy using microwave coagulation for small renal tumors. Eur Urol 2002;41:540-545, discussion 545.

-4 Lui KW, Gervais DA, Arellano RA, Mueller PR: Radiofrequency ablation of renal cell carcinoma. Clin Radiol 2003;58:905-913.

5 Su LM, Jarrett TW, Chan DY, Kavoussi LR, Solomon SB: Percutaneous computed tomography-guided radiofrequency ablation of renal masses in high surgical risk patients: preliminary results. Urology 2003;61:26-33.
-6 Goldberg SN, Gazelle GS, Mueller PR: Thermal ablation therapy for focal malignancy: a unified approach to underlying principles, techniques, and diagnostic imaging guidance. AJR Am J Roentgenol 2000;174:323331.

7 Hines-Peralta A, Goldberg SN: Review of radiofrequency ablation for renal cell carcinoma. Clin Cancer Res 2004;10:6328-6334.

>8 Yokoyama T, Egami K, Miyamoto M, Watanabe H, Hasegawa H, Iida S, Suzuki S, Nakamura Y, Okawa K, Hagiwara N, Takashima Y, Yoshioka M, Tajiri T, Onda M: Percutaneous and laparoscopic approaches of radiofrequency ablation treatment for liver cancer. J Hepatobiliary Pancreat Surg 2003;10:425427.

-9 Steinke K, Sewell PE, Dupuy D, Lencioni R, Helmberger T, Kee ST, Jacob AL, Glenn DW, King J, Morris DL: Pulmonary radiofrequency ablation - an international study survey. Anticancer Res 2004;24:339-343.
10 Wood BJ, Ramkaransingh JR, Fojo T, Walther MM, Libutti SK: Percutaneous tumor ablation with radiofrequency. Cancer 2002; 94:443-451.

11 Margulis V, Matsumoto ED, Taylor G, Shaffer S, Kabbani W, Cadeddu JA: Retrograde renal cooling during radio frequency ablation to protect from renal collecting system injury. J Urol 2005; 174:350-352.

12 Maeda M, Kimura M, Nakai M, Sahara S, Ishikawa $\mathrm{H}$, Minamiguchi $\mathrm{H}$, Yamada $\mathrm{K}$, Kawai N, Tanihata H, Kishi K, Terada M, Sato M: Percutaneous radiofrequency ablation for hepatocellular carcinoma: usefulness of combination with transcatheter arterial embolization. Jpn J Clin Radiol 2003;48: 930-934.

13 Chang I, Mikityansky I, Wray-Cahen D, Pritchard WF, Karanian JW, Wood BJ: Effects of perfusion on radiofrequency ablation in swine kidneys. Radiology 2004;231: 500-505. 
14 Ahmed M, Liu Z, Afzal KS, Weeks D, Lobo SM, Kruskal JB, Lenkinski RE, Goldberg SN: Radiofrequency ablation: effect of surrounding tissue composition on coagulation necrosis in a canine tumor model. Radiology 2004;230:761-767.

-15 Patterson EJ, Scudamore CH, Owen DA, Nagy AG, Buczkowski AK: Radiofrequency ablation of porcine liver in vivo: effects of blood flow and treatment time on lesion size. Ann Surg 1998;227:559-565.

16 Lu DS, Raman SS, Vodopich DJ, Wang M, Sayre J, Lassman C: Effect of vessel size on creation of hepatic radiofrequency lesions in pigs: assessment of the 'heat sink' effect. AJR Am J Roentgenol 2002;178:47-51.
7 Goldberg SN, Hahn PF, Halpern EF, Fogle R, Gazelle GS: Radiofrequency tissue ablation: effect of pharmacologic modulation of blood flow on coagulation diameter. Radiology 1998;209:761-769.

18 Goldberg SN, Ahmed M, Gazelle GS, Kruskal JB, Huertas JC, Halpern EF, Oliver BS, Lenkinski RE: Radiofrequency thermal ablation with adjuvant saline injection: effect of electrical conductivity on tissue heating and coagulation. Radiology 2001;219:157165.

19 Lobo SM, Afzal SK, Kruskal JB, Lenkinski RE, Gazelle GS, Goldberg SN: Radiofrequency thermal ablation using an adjuvant $\mathrm{NaCl}$ gel: effect of electrical conductivity on tissue coagulation (abstract). Radiology 2004;201: 398.
20 Goldberg SN, Gazelle GS, Mueller PR: Thermal ablation therapy for focal malignancy: a unified approach to underlying principles, techniques, and diagnostic imaging guidance. AJR Am J Roentgenol 2000;174:323331.

1 Zlotta AR, Wildschutz T, Raviv G, Peny MO, van Gansbeke D, Noel JC, Schulman CC: Radiofrequency interstitial tumor ablation (RITA) is a possible new modality for treatment of renal cancer: ex vivo and in vivo experience. J Endourol 1997;11:251-258. 